\title{
XAS, IR and XRD analysis for structural characterization of rare minerals: new occurrence of demantoid garnets in Sa Spinarbedda mine (Sardinia - Italy)
}

\author{
N. Precisvalle ${ }^{1^{*}}$, A. Martucci ${ }^{1}$, C. Bonadiman1, S. Pollastri ${ }^{2}$, C. Stani ${ }^{2}$ \\ ${ }^{I}$ Physics and Earth Sciences Department, University of Ferrara, Via Saragat 1, 44122 Ferrara, Italy. \\ ${ }^{2}$ Elettra - Sincrotrone Trieste, ss 14, $\mathrm{km}$ 163.5, 34149 Basovizza, Trieste Italy.
}

prcncl@unife.it

In this work, we present new geochemical and structural data in order to document a new occurrence of andradite garnet (garnet general formula $\left.\{\mathrm{X}\}_{3} \mathrm{Y}_{2}(\mathrm{Z})_{3} \mathrm{O}_{12}\right)$ "demantoid" variety" in Sardinia, Italy [1]. The crystal structure consists of a framework of alternating $\mathrm{ZO}_{4}$ tetrahedra and $\mathrm{YO}_{6}$ octahedra that share corners, with cavities in the $\mathrm{X}$ cations coordinated by 8 oxygen atoms in the form of a triangular dodecahedron. The yellowish green to intense green variety of andradite, called "demantoid", is a precious and greatly appreciated gemstone, mainly found in Russia, Namibia, Madagascar and Italy (Valmalenco, Lumbardy) [2]. The studied samples come from a new deposit from Domus de Maria municipality, nearby "Sa Spinarbedda" mine. This found is very peculiar, because although the beauty of these samples, it has not been previously described from Sardinia region. In this work we investigated the structural and chemical features of these new demantoid samples by combining electron microprobe analyses (EMPA), laser ablation-inductively coupled mass spectrometry (LA-ICP-MS), single crystal X-ray diffraction (XRSD), IR and X-ray absorption (XAS) spectroscopies. Chemical analyses revealed an enrichment of $\mathrm{Ca}$ and $\mathrm{Fe}$ and a low content of $\mathrm{Ti}$, $\mathrm{Mn}$ and $\mathrm{Al}$, thus confirming the andradite nature of the garnet. The $\mathrm{Cr}$ content $(\sim 8.73 \mathrm{ppm}$, mean) has been useful to confirm the demantoid variety of andradite. $\mathrm{Fe}$ and Mn K-edge XAS data were collected at the XAFS beamline (ELETTRA, Trieste, Italy) both in transmission (Fe) and fluorescence mode (Mn), using fixed exit Si (111) monochromator [4] to better understand the coordination number of both ions. Position of the absorption edge together with the pre-edge peaks analysis, point to the presence of only $\mathrm{Fe}^{3+}$ in octahedral coordination, confirming that the whole Fe content can be allocated in the Y crystallographic site. A more complex situation has been found for Mn where pre-edge peaks analysis on our spectrum indicate that Mn should be mainly in the form of $\mathrm{Mn}^{2+}$ and 8 -fold coordination, occupying the $\mathrm{X}$ crystallographic site, beside a small amount of $\mathrm{Mn}^{3+}$ is probably present in octahedral $\mathrm{Y}$ site. The infrared spectra of andradite crystals investigated at the SISSI beamline (ELETTRA, Trieste, Italy) show a prominent absorption band at about $3560 \mathrm{~cm}^{-1}$, suggesting the well-known hydrogarnet substitution of $\left(\mathrm{SiO}_{4}\right)_{4}$ with $\left(\mathrm{O}_{4} \mathrm{H}_{4}\right)_{4}$ [5][6]. These absorption features are related to hydroxide, which can be incorporated in the andradite structure in the form of structurally bonded $\mathrm{OH}$ groups, according to previous experimental findings [5].

X-ray single-crystal diffraction experiments refinement ( $I a \overline{3 d}$ space group) highlighted a unit cell volume (1757.15(2) $\left.\AA^{3}\right)$ larger than that reported usually in the literature thus confirming the presence of a slight water content [5]. The dodecahedral site X resulted to be partially occupied in a proportion of $\approx 96.2 \% \mathrm{Ca}$ and $\approx 3 \%$ of $\mathrm{Mn}^{+2}$. The octahedral site $\mathrm{Y}$ also resulted to be partially occupied in a proportion of $\approx 95.6 \% \mathrm{Fe}^{+3}$ and $\approx 4.5 \% \mathrm{Al}$, while the $\mathrm{Mn}^{+3}$ content was too low to be estimated. Then, according to Adamo et al. (2011) [6] the potential partial occupation of tetrahedral site has been checked. Actually, the site resulted occupied only for $\approx 98 \%$, the other $2 \%$ has been refined for $\mathrm{O}$ (same position and same thermal factor), suggesting the presence of structural water. Refining the site occupancy factor (s.o.f.) at the Si-site, modelled with the scattering curve of silicon alone in the X-ray structure refinement, we obtained s.o.f. value $\approx 98 \%$, which barely confirmed potential hydrogarnet substitution [i.e., $\left(\left(\mathrm{SiO}_{4}\right)_{4}\right.$ with $\left.\left(\mathrm{O}_{4} \mathrm{H}_{4}\right)_{4}\right]$.

[1] Grew, Edward \& Locock, A. \& Mills, S.J. \& Galuskina, Irina \& Galuskin, Evgeny \& Hålenius, Ulf. (2013). Am. Min. 98, 785-811.

[2] Štubňa, J., Bačík, P., Fridrichová, J., Hanus, R., Illášová, L., Milovská, S., ... \& Čerňanský, S. (2019). Minerals, 9(3), 164

[3] Geiger, C. A., \& Rossman, G. R. (2020). Am. Min. 105(4), 455-467

[4] Di Cicco, A., Aquilanti, G., Minicucci, M., Principi, E., Novello, N., Cognigni, A., \& Olivi, L. (2009). J. Phys. Conf. Ser. 190(1), 012043

[5] Amthauer, G. \& Rossman, G.R. (1998): The hydrous component in andradite garnet. Am. Mineral., 83, 835-840.

[6] Adamo, I., Gatta, G. D., Rotiroti, N., Diella, V., \& Pavese, A. (2011). Eur. J. Mineral. 23(1), 91-100

Keywords: XAS; XRD; IR, garnet, andradite, demantoid, new occurrence. 